\title{
GBMR
}

\section{The Quality of Annual General Meeting Minutes of Listed Companies in Malaysia}

Mohd Shazwan Bin Mohd Ariffin 1, Wan Nordin Bin Wan-Hussin 2, Siti Seri Delima Binti Abdul Malak3

1Othman Yeop Abdullah Graduate School of Business, Universiti Utara Malaysia, Malaysia,

E-mail: mohd_shazwan1@oyagsb.uum.edu.my

2Othman Yeop Abdullah Graduate School of Business, Universiti Utara Malaysia, Malaysia,

E-mail: wannordin@uum.edu.my

3Tunku Puteri Intan Shafinaz Schhol of Accounting, Universiti Utara Malaysia, Malaysia,

E-mail: seridelima@uum.edu.my

1Corresponding author: mohd_shazwan1@oyagsb.uum.edu.my

Received: November 302019 Revised: May 82020 Accepted: January 202020 Published: June 302020

\begin{abstract}
The annual general meeting (AGM) minutes act as an integral part of a good disclosure and transparency in delivering corporate information. Through the content of AGM minutes, shareholders can have an overview of the company's performance. The paper examines the indepth context of the AGM minutes of listed companies in Malaysia. Using the content analysis, a self-constructed checklist was developed to measure the quality of AGM minutes of listed companies in Malaysia. A sample of 115 AGM minutes from various sectors listed in Bursa Malaysia for the financial year ended December 31, 2016, was reported. The results indicate that the quality of AGM minutes discloses by listed companies relatively low consistent with the prior literature that sought for more exploration on the AGM. Using SPSS version 24, a descriptive analysis was presented in this paper. The low level of AGM minutes' disclosure among Malaysian listed companies suggests that these companies merely disclose within the mandatory requirements. The initiative by the Minority Shareholder Watch Group (MSWG) encourages more disclosure cause listed companies to disclosure additional information such as AGM minutes' content. The result of this study provides meaningful information, especially on the quality of AGM minutes' disclosure in Malaysian listed companies, which remained largely unexplored. The study provides insight contribution of the quality AGM minutes on the corporate website prior implementation of Companies Act 2016.
\end{abstract}

Keywords: AGM minutes, financial year, corporate website, companies, quality. 
Global Business Management Review, 2020

JUNE 2020

http://gbmr.oyagsb.uum.edu.my

\section{INTRODUCTION}

"The Annual General Meeting is an interesting event for a variety of reasons."

Apostolides, N. (2010: page 2)

From the international perspective, an annual general meeting (AGM) is used as a medium of communication between the management (directors) and its owners (shareholders) to discuss companies' performance and matters arising. Specifically, in Malaysia, the conduct of the AGM is under the purview of the Companies Commission of Malaysia (CCM) and is also monitored closely by the Bursa Malaysia Securities Berhad and Securities Commission of Malaysia, especially for public listed companies. As stipulated under section 340(1) of the Companies Act 2016,..." every public company either publicly listed or non-listed shall hold an Annual General Meeting in every calendar year in addition to any other meetings held during that period in order to discuss on the (a) audited financial statements and the reports for the financial year period, (b) election of the retiring directors, (c) to fix the appointment of the directors and directors fee and remuneration and (d) to translate any resolution or other business in accordance with the Act or the Constitution" (Chan, 2017; Shih, 2018).

Practically, the AGM minutes serve two purposes: (a) to the management, as a platform for the directors to have a meaningful discussion for strategic and company performance (Fung, 2014; López-Arceiz, Torres, \& Bellostas, 2019) and (b) to the shareholders, AGM minutes provide an alternative solution for absentee shareholders to keep track of the AGM even though they did not physically attend the meeting. Besides that, AGM minutes act as a medium for shareholders to exercise their power and right (Mohamad, 2002).

Traditionally, Mort (1995) divided the AGM minutes into four elements. First, as a fresh reminder of the previous meeting discussion, secondly, deliberation of matters arising. Next, the potential for investors' investment and followed by a record of documentation ((Mort, 1995) as retrieved by Salleh, Hamid, Harun, Bidin \& Ghads, 2019). Despite its role, in Malaysia, there is no specific specimen of the AGM minutes' context until the recent publication of the AGM Corporate 
Global Business Management Review, 2020

JUNE 2020

http://gbmr.oyagsb.uum.edu.my

Governance Checklist for Shareholders established to promote its purpose (Securities Commission of Malaysia, 2020: p. 16). Back then, The Malaysian Institute of Chartered Secretaries and Administrators (MAICSA) through its Recommended Practice Guide on Minutes Writing and Corporate Governance ASEAN Scorecard cooperated to encourage more disclosure in a company's corporate website (Bryan \& Farrell, 2009; Ariffin, Hussain \& Malak, 2019).

Bursa Malaysia Securities Berhad acts as a pivotal example for other listed companies. Through its minutes, lots of meaningful information are disclosed to the investors (Najid \& Rahman, 2011). Among the quality general meeting minutes produced by Bursa Malaysia Securities Berhad consist of the notice of the meeting as to when the AGM will be held, list of attendance of the meeting frequently asked questions and its answers, the number of pages for AGM minutes, duration of the meeting and chairman signature as a proof that the meeting was held (Wahab, How \& Verhoeven, 2008; Ameer \& Rahman, 2009). More importantly, these are the items that are also disclosed by top listed companies in their AGM minutes (OECD, 1999; Guide, 2017; Menon; 2017). For this study's purpose, the researcher intends to examine the content quality of the AGM minutes based on these criteria among all Malaysian listed companies based on the financial year ended December 31, 2016.

\subsection{Overview}

The debate about additional disclosure had been raised over the decades. As such, the disclosure of corporate information must include accountability and transparency as an indicator of good governance (Solomon, 2007; Brenna \& Solomon, 2008). Moreover, Ho's study also claims that a higher level of disclosure leads to better company performance (Ho \& Wong, 2001; Kelton \& Yang, 2008). However, critics on additional disclosure are also one of the academician's primary considerations (Laksmana, 2008; Allegrini \& Greco, 2013). For instance, extensive information such as sensitive information may be harmful to the companies, thus leading to corporate governance scandals (Ben-Amar, Chang \& Mcllkenny, 2017; Helfaya \& Moussa, 2017).

The timeframe of the financial year ended December 31, 2016, was chosen because it is the transition period from Companies Act 1965 to Companies Act 2016 (CA2016) (Avaniappan \& 
Global Business Management Review, 2020

JUNE 2020

http://gbmr.oyagsb.uum.edu.my

Anuar, 2017; Chan, 2019). With the adoption of CA2016, the content of the general meeting must consist of the agenda of the re-election of the retiring directors, approval of the director's fees, and re-appointment of the auditors for the next financial year (Council, 2012; Guide, 2017).

The enforcement of the publication of general meeting minutes on companies' corporate website based on Bursa Malaysia Listing Requirement under Chapter 9 Paragraph 9.21(1)(b) states that " $a$ public company listed under Main or ACE Market must ensure that their website provides a summary of the key matters discussed at the AGM, as soon as practicable after the conclusion of the AGM." (Bursa Malaysia Securities Berhad, 2018).

\subsection{Enforcement bodies}

The Securities Commission of Malaysia's (SC) role is to monitor listed companies' adherence to the enforcement by Bursa Malaysia Securities Berhad. Through SC, listed companies have been categorised based on their respective level of market capitalisation (Malaysian Securities Commission, 2017: p. 10; Zulkifli, 2019). According to Malaysia-ASEAN Corporate Governance Report in 2016, overall, almost 48 percent of listed companies are willing to publish AGM minutes on their corporate website in 2016 compared to 38 percent in 2015 (Malaysia-ASEAN Corporate Governance Report, 2017; Malaysian Code on Corporate Governance, 2017; Malaysian Corporate Governance Monitor, 2019).

\subsection{REVIEW OF LITERATURE}

As mentioned earlier, good governance is mostly associated with accountability and transparency (López-Arceiz et al., 2019). Besides that, based on Corruption Perception Index (CPI) 2017 , Malaysia has been ranked at number 62 out of 180 countries comprised of Asia Pacific, SubSaharan Africa, the Middle East, and Northern Africa, Americas, and Europe and Central Asia for good transparency which provides strong evidence that Malaysia practices a balance of good governance in its administration (Transparency International, 2017). Hence, transparency can be defined as the usefulness of information or resources; meanwhile, and accountability is associated with the responsibility of the action taken (McGee, \& Gaventa, 2011). In Malaysia, the SC 
Global Business Management Review, 2020

JUNE 2020

http://gbmr.oyagsb.uum.edu.my

produced a Blueprint in 2011 that comprises several characteristics to promote good governance among listed companies (Blueprint, 2011).

Moreover, through better governance, bureaucracy, corruption, and integrity cannot exist in the organization including listed companies (La Porta, Lopez-de-Silanes, Shleifer \& Vishny, 2000; Salim, 2017). However, most of the prior studies lack research on the AGM, especially on the minutes itself.

AGM is a unique method of communication that is seldom studied by researchers. Thus, by studying on this perspective, the study may bring the need for quality AGM minutes to be published on corporate websites as promoted by the Malaysian Minority Shareholders Watch Group (MSWG). Through more information, the study aims to promote Malaysia as a role model for best practice of good governance, especially towards achieving Vision 2020 (Hamid, 1995).

As such, most of the literature on AGM focused on the AGM process (Catasús \& Johed, 2007), the ritual of AGM meeting (Apostolides, 2010), and good practices of general meetings (González, Guzmán, Prada \& Trujillo, 2014). In Malaysia itself, a lack of studies on the AGM minutes has been documented. The pioneer theory towards disclosure seems to be from the perspective of agency cost theory (Fama \& Jensen, 1983). Through this theory, accountability and transparency co-exist through quality AGM minutes' disclosure. On this ground, the agency proposed for the cooperation between the agent (directors) and its principal (shareholders). Without a doubt, the theory encourages mutual understanding between the two actors towards better accountability and transparency.

\subsection{Quality of AGM minutes published on corporate website}

Minutes provide a medium of interaction between the company's management and its owners (Cordery, 2013). As such, frequently asked questions serve as a guide for potential and absentee investors at the general meeting. Despite its benefit, a drawback of disclosing AGM minutes on the corporate website is it may erode a company's competitiveness by exposing matters such as the discussion on the company's future prospects and level of investor confidence (Fama \& Jensen, 
Global Business Management Review, 2020

JUNE 2020

http://gbmr.oyagsb.uum.edu.my

1983). Besides that, through public issuance, companies of smaller size tend to be supressed or dominated by more prominent companies (Opler \& Sokobin, 1995).

The enforcement by the regulatory bodies under Chapter 9 Paragraph 9.21(1)(b) on key matters discussed after the general meeting supports the importance of this study mainly on the criteria of quality AGM minutes to be published on the corporate website (Guide, 2017). The evidence can be seen where regulatory bodies such as Bursa Malaysia Securities Berhad always updates its communication notes/guides to maintain best practices among listed companies in Malaysia. The updates of the information can be seen through Bursa Malaysia Securities Berhad's corporate website itself.

For this study's scope, the literature covered discussion on the disclosure of corporate information involving listed companies (Nyahas, Ntayim Kamukama \& Munene, 2018). Back in 2012, Rouf also raised his concern on the extensive information beyond normal norms or laws reported in the financial reports for shareholder's protection (Akhtaruddin \& Rouf, 2012: p. 48). Thus, most of the disclosure covered the areas of the strategic forecast, environmental impact, stakeholder's communication, and ethical consideration (Akhtaruddin \& Rouf, 2012).

Even though this study specifically focuses on quality AGM minutes disclosed on the corporate website, there are also some drawbacks of voluntary disclosure (Palmer, 2000). Besides the exposure of confidential and sensitive information, the more corporate information is published, the higher the probability of risk incidents to the listed companies (Palmer, 2000: p 7). The actors related to disclosure, such as top management, legal experts, and professional accountants, will not be covered in this study.

\subsection{Research Framework}

The research framework of the study is presented in this section. 


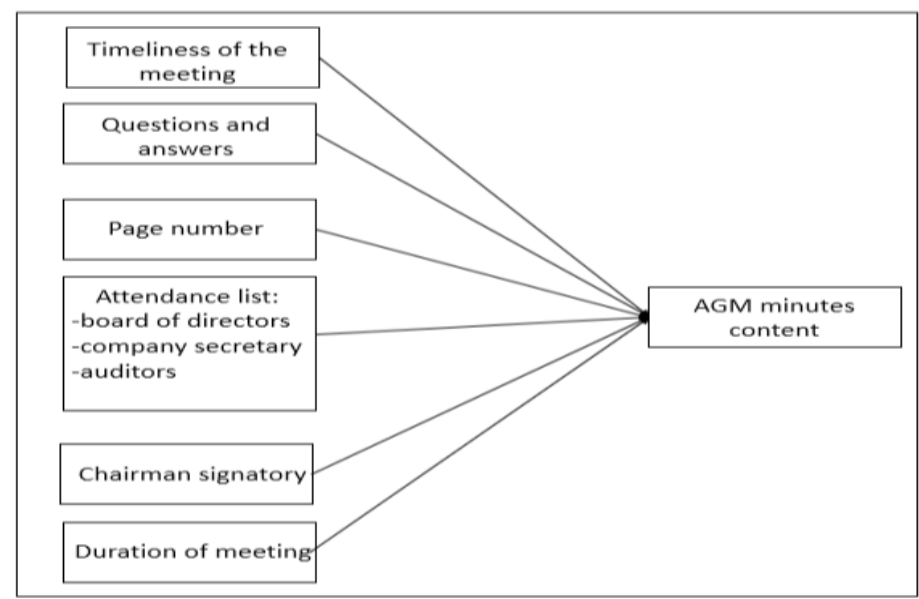

Figure 1: The quality of AGM minutes on corporate website.

Source: Drawn by the author (2020)

As mentioned earlier, not much literature tends to discuss AGM minutes published on the corporate website, especially involving Malaysian listed companies. From the researcher's point of view, the quality of AGM minutes comprises of (a) timeliness of the meeting, (b) questions and answers, (c) page number, (d) attendance list, (e) chairman signature and (f) duration of the meeting.

\subsection{Timeliness of the meeting}

Timeliness of the meeting covers the period from the issuance of the notice of the meeting until the day of the meeting. Notice of the meeting will provide some general information such as the date of the upcoming general meeting, venue, time, and place of the general meeting to be held. Due to its importance, Bursa Malaysia Securities Berhad makes it mandatory for all listed companies to publish the notice of the meeting on the Bursa Malaysia corporate website prior to the general meeting. Besides that, the notice also benefits the shareholders in managing their time for the general meeting (Black, Taylor, Caley \& Clark, 1998). Furthermore, if the shareholders are unable to attend the general meeting, a proxy or corporate representative will attend the general meeting on behalf of the shareholders (Cziraki, Renneboog \& Szilagyi, 2010).

From the regulatory perspective, the timeliness of the meeting must be within CA2016's jurisdiction. Section 316(2)(a) of CA2016 clearly states that notice of the general meeting must be 
Global Business Management Review, 2020

JUNE 2020

http://gbmr.oyagsb.uum.edu.my

published on Bursa Malaysia's website 21 days prior to the scheduled general meeting date (Companies Act 2016 on Section 316(2)(a)). In this study, surprisingly, on the Bursa Malaysia website, there were a few listed companies that did not comply with the duration of giving notice of the meeting. As supported by Edmonds' study (2017), among the main concerns of noncompliance is because professional auditors face huge burden or pressure to comply with the deadline for completion of the annual reports (Edmonds, Vermeer \& Vermeer, 2017).

\subsection{Questions and answers}

Guided by Bursa Malaysia Securities Berhad's AGM minutes sample, almost all listed companies include frequently asked questions and answers recorded within the AGM minutes (Gonzalez, Guzman, Prada \& Trujillo, 2014). Few scholars also encourage the questions and answers session during the general meeting (Carrington \& Johed, 2007). Also, it also promotes more shareholder involvement, thus leading towards shareholder's activism (Yang, Uysal \& Taylor, 2018). One of the possible reasons for having frequently asked questions and answers was to attract more shareholders to exercise their right and voting power (Apostolides, 2010).

The quality of AGM minutes can be seen through listed companies that take the initiative to compile all the questions related to the meeting agenda and record them in the minutes. Yang's study stressed that shareholders may influence the directors' decision making (Yang, Uysal \& Taylor, 2018). For the shareholders, as long as they can gain benefits from the companies, the disclosure of the information can be an effective medium of communication (Certo, 2003). The argument is duly supported by Zeng as the ultimate agency cost theory towards profit maximization (Zeng, 2016).

\subsection{Page number}

Not much literature stressed the importance of page numbers in annual reports (Guide, 2017). However, Rita (2016) mentioned that the page number indicates how informative corporate information is (Rita, \& Fern, 2016). One of the examples come from Bursa Malaysia Securities Berhad's AGM minutes itself. Due to limited studies on the page number, this study will raise the importance of page number, which will be elaborated in the findings section. 
Global Business Management Review, 2020

JUNE 2020

http://gbmr.oyagsb.uum.edu.my

\subsection{Attendance list}

Specifically, a good quality AGM minute will show the list of attendees of the meeting, which comprises of the directors, professional accountants, top management, and a number of shareholders. According to Chobpichein (2008), the attendance list is concrete evidence of the resolution made by the decision-maker (Chobpichien, Haron, \& Ibrahim, 2008). Under CA2016 for instance, the scrutineer is responsible for ensuring that the meeting is attended by valid shareholders (CA2016).

\subsection{Chairman signatory}

Quality AGM minutes can also be evidenced through the chairman's signature. The chairman's signature indicates the proof of documentation of the general meeting. As such, signature by the authorised person indicates the trustworthiness of the documentation (Cadbury Committee, 1992).

One of the purposes of the chairman's signature can be seen from the audit trail of evidence (Shackleton, Cordes, \& Caulfield, 2011). Due to this reason, the AGM minutes must be properly recorded, signed, and kept at the registered office for routine accounting check (CA2016). The record-keeping and documentation leads to the quality level of the data (Palmer, 2000).

\subsection{Duration of the meeting}

The duration of the meeting is indicated based on the time the general meeting started until its end. Most of the studies tend to associate that the longer the meeting, the more valuable the information generated. Generally, Malaysian listed companies hold their AGM within 30 minutes. However, top listed companies and government linked companies (GLCs) such as Sime Darby Group, Petronas Gas Group Berhad and IOI Group Berhad have a meeting longer than 30 minutes.

\subsection{METHODOLOGY}

As a descriptive analysis, this study utilised the IBM SPSS Statistics tools version 24 in examining and analysing the data collection. Besides using simple descriptive analysis, this study provides some discussion on the quality of AGM minutes published on the corporate website. Besides 
Global Business Management Review, 2020

JUNE 2020

http://gbmr.oyagsb.uum.edu.my

statistical software, by using secondary data collection, the data were gathered, coded and analysed using Thomson Reuters Datastream, Bloomberg database, and manually hand collecting the data.

\subsection{Data collection}

Based on manual hand collection, all listed companies during the financial year ended December 31, 2016, were observed, monitored and recorded until the end of 2017. Thus, a sample of 262 companies was available for the study consisting of 79 which did not disclose their AGM minutes, 68 which partially disclosed their AGM minutes and 115 which fully disclosed their AGM minutes on their corporate website. For the measurement of the quality of AGM minutes, based on preliminary studies, only 115 companies that fully disclosed their AGM minutes will be examined, recorded and analysed for this study. The full AGM minutes can be viewed in the corporate website's section/column either in "Corporate Governance, Investor Relations or Media Relations". An example of the AGM meeting will appear with a heading title such as the "Annual General Meeting of ... or A Summary of Annual General Meeting". A good quality AGM minutes will have the following characteristics: (a) timeliness of the meeting, (b) questions and answers, (c) page number, (d) attendance list, (e) chairman signature and (f) duration of the meeting.

\subsection{ANALYSIS AND RESULTS}

\subsection{Descriptive analysis for the number of companies and nature of the business}

Using descriptive analysis, most of the good quality AGM minutes come from airlines, automobiles, broadcast and entertainment, building material and fixtures, business support systems, communication, vehicles, trucks, consumers electronics, drivers, industries, electrical equipment, fish farm plantation, food products, full line insurance, gambling, heavy construction, industries and office, integrated oil and gas, iron and steel, media agencies, mortgage finance, oil equipment and services, personal products, casualty insurance, real estate investment trust (REITs), tires, transport services and water supplier. The nature of business is also consistent with Thomson Reuters Datastream and Bloomberg database. 
Global Business Management Review, 2020

JUNE 2020

http://gbmr.oyagsb.uum.edu.my

Companies of similar nature of business were grouped into several categories. Heavy construction consists of Ahmad Zaki Resources Berhad, ARK Resources Berhad, Bina Darulaman Berhad, Bina Puri Holdings Berhad, DKLS Industries Berhad, Eversendai Berhad, Kerjaya Prospect Group Berhad, Malaysian Resources Corporation Berhad, and TRC Synergy Berhad. Meanwhile, for REITs, the companies consist of Encorp Berhad, I-Berhad, IGB Berhad, KLCC Property Holdings Berhad, Pasdec Holdings Berhad, Sunway Group Berhad, and UEM Sunrise Berhad.

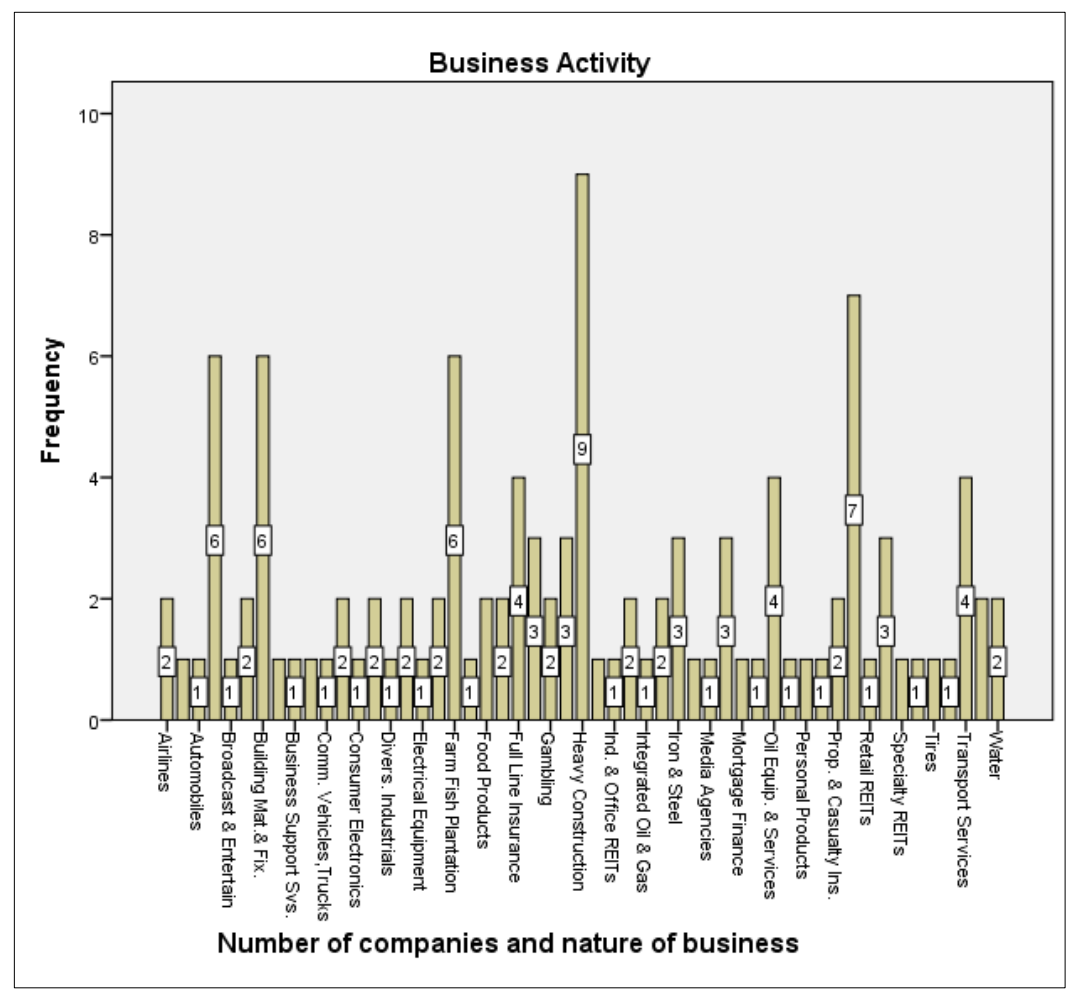

Figure 2: Number of companies and the nature of the business analysed in the study.

Source: Drawn by the author (2020)

\subsection{Descriptive analysis of the study}

Table 1: Sample list of the companies with AGM minutes' context for the financial year ended December 31, 2016.

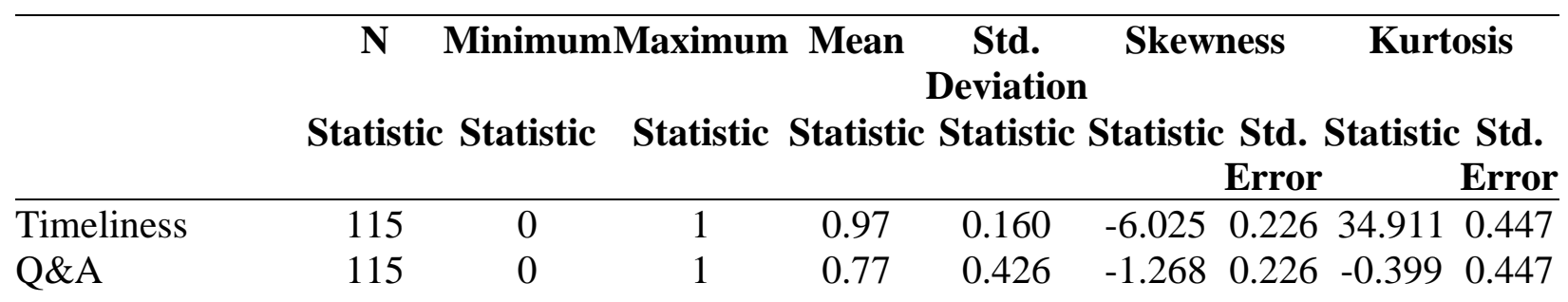


Global Business Management Review, 2020

JUNE 2020

http://gbmr.oyagsb.uum.edu.my

\begin{tabular}{llllllllll} 
Attendance List & 115 & 0 & 1 & 0.63 & 0.486 & -.528 & 0.226 & -1.752 & 0.447 \\
Outcome Reso & 115 & 0 & 1 & 0.83 & 0.381 & -1.743 & 0.226 & 1.058 & 0.447 \\
Chairman Sign & 115 & 0 & 1 & 0.53 & 0.501 & -.1240 & 0.226 & -2.020 & 0.447 \\
Dur Meeting & 115 & 0 & 1 & 0.90 & 0.295 & -2.786 & 0.226 & 5.864 & 0.447 \\
\hline
\end{tabular}

Table 1 provides a descriptive analysis of the study focused on the quality of AGM minutes on corporate website based on timeliness, frequently asked questions and answers, attendance list, resolution outcome, chairman signature, and duration of the meeting. Overall, this study used the normality test based on skewness and kurtosis analysis to indicate the normality distribution. Generally, the normality distribution must be within zero to three (in standard error). From the table given, it shows that the skewness and kurtosis is within the range of the study.

Skewness is used to indicate the amount of imbalance distribution around its mean. The skewness to the left with the value of negative indicates that the left tail is longer compared to the right tail and vice versa. Meanwhile, kurtosis is used to indicate the flatness of the distribution to the normal distribution of the data. Higher kurtosis indicates that the data has a distinctive peak near to the mean and vice versa. In addition, George and Mallery (2010) further mentioned that skewness and kurtosis must be within a range of -2 to +2 to be considered for further analysis (Tabachnick, Fidell \& Ullman, 2007; George \& Mallery, 2010).

The descriptive analysis results show that the mean for timeliness is 0.97 with a minimum of 0 and maximum of 1 , while the value of standard deviation is 0.16 , followed by Q\&A mean of 0.77 while the value of standard deviation is 0.426 , meanwhile for attendance list, the mean is 0.63 while the value of standard deviation is 0.486 , outcome resolution provided a mean of 0.83 and a value of the standard deviation of 0.381 . Meanwhile, the chairman's signature shows a mean of 0.53 and a standard deviation of 0.501 . Besides that, the duration of the meeting, Dur_Meeting, shows a mean of 0.9 and a standard deviation of 0.295 , respectively. 
Global Business Management Review, 2020

JUNE 2020

http://gbmr.oyagsb.uum.edu.my

Table 2: Sample list of the companies with AGM minutes' context for the financial year ended December 31, 2016.

\begin{tabular}{|c|c|c|c|c|c|c|c|c|}
\hline No & Name & 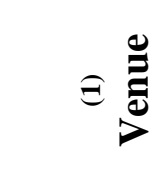 & สิ & ब. & 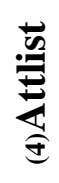 & 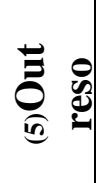 & 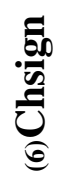 & 志包 \\
\hline 1 & ABLEGROUP & SEL & 1 & 1 & 1 & 1 & 1 & 1 \\
\hline 2 & ACOUSTECH & $\mathrm{KL}$ & 1 & 1 & 0 & 1 & 0 & 1 \\
\hline 3 & AEON CO.(M) & KL & 1 & 1 & 1 & 1 & 0 & 1 \\
\hline 4 & AFFIN HOLDINGS & $\mathrm{KL}$ & 1 & 0 & 0 & 1 & 0 & 1 \\
\hline 5 & AHMAD ZAKI RESOURCES & KL & 1 & 0 & 0 & 1 & 0 & 1 \\
\hline 6 & AIRASIA & SEL & 1 & 1 & 0 & 1 & 0 & 1 \\
\hline 7 & AIRASIA X & SEL & 1 & 1 & 0 & 0 & 0 & 1 \\
\hline 8 & AL-AQAR HEALTHCARE REIT & JHR & 1 & 0 & 1 & 1 & 0 & 1 \\
\hline 9 & ALLIANZ MALAYSIA & KL & 1 & 1 & 1 & 0 & 1 & 1 \\
\hline 10 & AMWAY (MAL.) HDG. & SEL & 1 & 1 & 0 & 1 & 1 & 1 \\
\hline 11 & ARK RESOURCES & $\mathrm{KL}$ & 1 & 0 & 0 & 1 & 1 & 1 \\
\hline 12 & ASIA POLY HOLDINGS & SEL & 1 & 0 & 0 & 0 & 0 & 0 \\
\hline 13 & AXIATA GROUP & KL & 1 & 0 & 0 & 0 & 0 & 1 \\
\hline 14 & AXIS REAL ESTATE INVESTMENT TRUST & SEL & 1 & 1 & 1 & 1 & 1 & 1 \\
\hline 15 & BIMB HOLDINGS & KL & 1 & 1 & 1 & 1 & 1 & 1 \\
\hline 16 & BINA DARULAMAN & KL & 1 & 1 & 0 & 0 & 1 & 1 \\
\hline 17 & BINA PURI HOLDINGS & SEL & 1 & 1 & 0 & 1 & 1 & 1 \\
\hline 18 & BINTULU PORT HOLDINGS & SRWK & 1 & 1 & 1 & 1 & 1 & 1 \\
\hline 19 & BOUSTEAD HEAVY INDS. & SEL & 1 & 1 & 1 & 0 & 1 & 1 \\
\hline 20 & BRIT.AMER.TOB.(MALAYSIA) & KL & 1 & 1 & 1 & 1 & 0 & 1 \\
\hline 21 & BURSA MALAYSIA & KL & 1 & 1 & 1 & 1 & 1 & 1 \\
\hline 22 & CAHYA MATA SARAWAK & SRWK & 1 & 1 & 1 & 1 & 1 & 1 \\
\hline 23 & CAM RESOURCES & KL & 1 & 1 & 1 & 1 & 0 & 1 \\
\hline 24 & CCM DUOPH.BIOTECH & SEL & 1 & 1 & 1 & 1 & 0 & 1 \\
\hline 25 & CHEMICAL MALAYSIA & $\mathrm{KL}$ & 1 & 1 & 1 & 1 & 1 & 1 \\
\hline
\end{tabular}


Global Business Management Review, 2020

JUNE 2020

http://gbmr.oyagsb.uum.edu.my

Table 1: Sample list of the companies with AGM minutes' context for the financial year ended December 31, 2016 (Continued)

\begin{tabular}{|c|c|c|c|c|c|c|c|c|}
\hline 26 & CIMB GROUP HOLDINGS & KL & 1 & 1 & 1 & 1 & 1 & 1 \\
\hline 27 & CLASSIC SCENIC & KL & 1 & 1 & 0 & 1 & 0 & 1 \\
\hline 28 & CNI HOLDINGS & SEL & 1 & 1 & 0 & 1 & 1 & 1 \\
\hline 29 & DAIBOCHI PLASTIC \& PACK. INDUSTRY & MEL & 1 & 1 & 1 & 1 & 1 & 1 \\
\hline 30 & DAYANG ENTER.HDG. & SRWK & 1 & 0 & 0 & 1 & 0 & 1 \\
\hline 31 & DIGI.COM & KL & 1 & 1 & 1 & 1 & 1 & 1 \\
\hline 32 & DKLS INDUSTRIES & PER & 1 & 0 & 0 & 1 & 0 & 1 \\
\hline 33 & ECM LIBRA FINANCIAL GP. & KL & 1 & 1 & 1 & 1 & 0 & 1 \\
\hline 34 & EFFICIENT E-SOLUTIONS & SEL & 1 & 0 & 1 & 1 & 1 & 1 \\
\hline 35 & ENCORP BERHAD & SEL & 1 & 0 & 0 & 1 & 0 & 1 \\
\hline 36 & EURO HOLDINGS & SEL & 1 & 0 & 0 & 1 & 0 & 1 \\
\hline 37 & EVERGREEN FIBREBOARD & JHR & 1 & 1 & 1 & 1 & 1 & 1 \\
\hline 38 & EVERSENDAI & KL & 0 & 0 & 0 & 0 & 0 & 0 \\
\hline 39 & FAR EAST HOLDINGS & PHG & 1 & 0 & 0 & 1 & 0 & 1 \\
\hline 40 & FELDA GLOBAL VENT.HDG./FGV HLDG. BERHAD & KL & 1 & 1 & 0 & 1 & 0 & 1 \\
\hline 41 & GAS MALAYSIA & KL & 1 & 1 & 1 & 1 & 0 & 1 \\
\hline 42 & GENTING MALAYSIA & $\mathrm{KL}$ & 1 & 1 & 0 & 1 & 0 & 0 \\
\hline 43 & GOLDIS & KL & 1 & 1 & 1 & 1 & 1 & 1 \\
\hline 44 & GOODWAY INTEGRATED INDS. & SEL & 1 & 1 & 1 & 0 & 1 & 0 \\
\hline 45 & GUH HOLDINGS & PEN & 1 & 0 & 0 & 1 & 0 & 1 \\
\hline 46 & HAP SENG CONSOLIDATED & KL & 1 & 1 & 1 & 1 & 0 & 1 \\
\hline 47 & HAP SENG PLTNS.HDG. & KL & 1 & 1 & 1 & 1 & 1 & 1 \\
\hline 48 & I-BERHAD & SEL & 1 & 1 & 1 & 1 & 1 & 1 \\
\hline 49 & IGB & KL & 1 & 1 & 1 & 1 & 1 & 1 \\
\hline 50 & IGB REAL ESTATE INVESTMENT TRUST & KL & 1 & 1 & 1 & 0 & 1 & 1 \\
\hline 51 & IHH HEALTHCARE & KL & 1 & 1 & 0 & 0 & 0 & 1 \\
\hline 52 & INCH KENNETH KAJANG (KLS) & KL & 0 & 0 & 0 & 1 & 1 & 1 \\
\hline 53 & INNITY & SEL & 1 & 1 & 0 & 0 & 0 & 0 \\
\hline 54 & JCBNEXT BERHAD & KL & 1 & 1 & 0 & 1 & 0 & 1 \\
\hline
\end{tabular}


Global Business Management Review, 2020

JUNE 2020

http://gbmr.oyagsb.uum.edu.my

Table 1: Sample list of the companies with AGM minutes' context for the financial year ended December 31, 2016 (Continued)

\begin{tabular}{|c|c|c|c|c|c|c|c|c|}
\hline 55 & KERJAYA PROSPEK GROUP & KL & 1 & 0 & 1 & 0 & 0 & 1 \\
\hline 56 & KIA LIM & JHR & 1 & 1 & 0 & 1 & 0 & 1 \\
\hline 57 & KLCC PROPERTY HOLDINGS & KL & 1 & 1 & 1 & 1 & 1 & 1 \\
\hline 58 & KONSORTIUM TRANSNASIONAL & $\mathrm{KL}$ & 1 & 1 & 1 & 1 & 1 & 1 \\
\hline 59 & KPJ HEALTHCARE & JHR & 0 & 1 & 1 & 1 & 1 & 1 \\
\hline 60 & KUMPULAN PERANGSANG SELANGOR & SEL & 1 & 1 & 1 & 1 & 1 & 1 \\
\hline 61 & LAFARGE MALAYSIA & KL & 1 & 1 & 1 & 1 & 0 & 1 \\
\hline 62 & LANDMARKS & KL & 1 & 1 & 0 & 0 & 0 & 0 \\
\hline 63 & LEON FUAT & KL & 1 & 1 & 1 & 1 & 1 & 1 \\
\hline 64 & LII HEN INDS. & JHR & 1 & 1 & 1 & 1 & 1 & 1 \\
\hline 65 & LNG RESOURCES & PEN & 1 & 1 & 0 & 0 & 0 & 0 \\
\hline 66 & LPI CAPITAL & KL & 1 & 1 & 1 & 1 & 0 & 1 \\
\hline 67 & MAA GROUP & KL & 1 & 1 & 1 & 1 & 1 & 1 \\
\hline 68 & MAGNUM & SEL & 1 & 1 & 0 & 1 & 0 & 0 \\
\hline 69 & MALAYAN BANKING & KL & 1 & 1 & 1 & 1 & 0 & 1 \\
\hline 70 & MALAYAN FLOUR MILLS & KL & 1 & 1 & 1 & 1 & 1 & 1 \\
\hline 71 & MALAYSIA AIRPORTS HDG. & SEL & 1 & 1 & 1 & 1 & 1 & 1 \\
\hline 72 & MALAYSIA BUILDING SOC. & KL & 1 & 1 & 1 & 1 & 1 & 1 \\
\hline 73 & MALAYSIA MAR.\& HVY.ENGR. HDG. & KL & 1 & 0 & 1 & 1 & 0 & 1 \\
\hline 74 & MALAYSIA SMELTING & PEN & 1 & 1 & 1 & 1 & 1 & 1 \\
\hline 75 & MALAYSIAN RES. & KL & 1 & 1 & 1 & 1 & 1 & 1 \\
\hline 76 & MANULIFE HOLDINGS & KL & 1 & 1 & 1 & 1 & 1 & 1 \\
\hline 77 & MASTER-PACK GROUP & PEN & 1 & 1 & 1 & 1 & 1 & 1 \\
\hline 78 & MAXIS & KL & 1 & 1 & 0 & 0 & 0 & 1 \\
\hline 79 & MBM RESOURCES & KL & 1 & 1 & 0 & 0 & 1 & 1 \\
\hline 80 & MEDIA PRIMA & SEL & 1 & 0 & 1 & 1 & 0 & 1 \\
\hline 81 & MHC PLANTATIONS & PER & 1 & 1 & 1 & 1 & 1 & 1 \\
\hline 82 & ML GLOBAL & SEL & 1 & 0 & 1 & 1 & 0 & 0 \\
\hline 83 & MMC & KL & 1 & 1 & 1 & 1 & 1 & 1 \\
\hline
\end{tabular}


Global Business Management Review, 2020

JUNE 2020

http://gbmr.oyagsb.uum.edu.my

Table 1: Sample list of the companies with AGM minutes' context for the financial year ended December 31, 2016 (Continued)

\begin{tabular}{|c|c|c|c|c|c|c|c|c|}
\hline 84 & MPHB CAPITAL & SEL & 1 & 0 & 1 & 1 & 0 & 1 \\
\hline 85 & MUDA & SEL & 1 & 1 & 1 & 1 & 1 & 1 \\
\hline 86 & NESTLE (MALAYSIA) & KL & 1 & 1 & 1 & 1 & 0 & 1 \\
\hline 87 & NI HSIN RESOURCES & $\mathrm{KL}$ & 1 & 0 & 1 & 1 & 1 & 1 \\
\hline 88 & PASDEC HOLDINGS & PHG & 1 & 1 & 0 & 1 & 0 & 1 \\
\hline 89 & PETRA ENERGY & SEL & 1 & 1 & 1 & 1 & 1 & 1 \\
\hline 90 & PETRONAS CHEMICALS GP. & $\mathrm{KL}$ & 1 & 1 & 1 & 1 & 1 & 1 \\
\hline 91 & PETRONAS DAGANGAN & KL & 1 & 1 & 1 & 1 & 1 & 1 \\
\hline 92 & PETRONAS GAS & KL & 1 & 1 & 1 & 1 & 1 & 1 \\
\hline 93 & PRG HOLDINGS & SEL & 1 & 0 & 1 & 1 & 1 & 1 \\
\hline 94 & PUBLIC BANK & $\mathrm{KL}$ & 1 & 1 & 1 & 1 & 0 & 1 \\
\hline 95 & RHB BANK BHD & KL & 1 & 1 & 1 & 1 & 1 & 1 \\
\hline 96 & RIVERVIEW RUBBER ESTS. & PER & 1 & 1 & 0 & 1 & 0 & 1 \\
\hline 97 & SMIS & KL & 1 & 1 & 1 & 1 & 1 & 1 \\
\hline 98 & SUNWAY & SEL & 1 & 1 & 1 & 0 & 1 & 1 \\
\hline 99 & SURIA CAPITAL HOLDINGS & $\mathrm{SBH}$ & 1 & 1 & 1 & 1 & 1 & 1 \\
\hline 100 & SYARIKAT TAKAFUL MAL. & $\mathrm{KL}$ & 1 & 1 & 1 & 1 & 0 & 1 \\
\hline 101 & TA ANN HOLDINGS & SRWK & 1 & 1 & 1 & 1 & 1 & 1 \\
\hline 102 & TADMAX RESOURCES & KL & 1 & 1 & 1 & 1 & 0 & 1 \\
\hline 103 & TALIWORKS & KL & 1 & 1 & 0 & 1 & 0 & 1 \\
\hline 104 & TELEKOM MALAYSIA & KL & 1 & 1 & 1 & 1 & 1 & 1 \\
\hline 105 & TEO SENG CAPITAL & JHR & 1 & 0 & 0 & 1 & 1 & 1 \\
\hline 106 & TRC SYNERGY & KL & 1 & 0 & 0 & 1 & 0 & 0 \\
\hline 107 & TUNE PROTECT GROUP & SEL & 1 & 1 & 0 & 0 & 0 & 1 \\
\hline 108 & TURBO-MECH & SEL & 1 & 0 & 1 & 1 & 1 & 1 \\
\hline 109 & UEM EDGENTA & SEL & 1 & 0 & 0 & 1 & 1 & 1 \\
\hline 110 & UEM SUNRISE & SEL & 1 & 1 & 1 & 1 & 0 & 1 \\
\hline 111 & UMW HOLDINGS & SEL & 1 & 1 & 1 & 1 & 0 & 1 \\
\hline 112 & VELESTO ENERGY BERHAD & KL & 1 & 1 & 1 & 1 & 1 & 1 \\
\hline
\end{tabular}


Global Business Management Review, 2020

JUNE 2020

http://gbmr.oyagsb.uum.edu.my

Table 1: Sample list of the companies with AGM minutes' context for the financial year ended December 31, 2016 (Continued)

\begin{tabular}{|c|l|l|c|c|c|c|c|c|}
\hline 113 & WARISAN TC HOLDINGS & KL & 1 & 1 & 1 & 1 & 0 & 1 \\
\hline 114 & WESTPORTS HOLDINGS & KL & 1 & 1 & 0 & 1 & 1 & 1 \\
\hline 115 & YUNG KONG GALVANISING INDS. & SEL & 1 & 0 & 0 & 1 & 0 & 0 \\
\hline \multicolumn{1}{|}{ TOTAL } & & $\mathbf{1 1 1}$ & $\mathbf{8 8}$ & $\mathbf{7 2}$ & $\mathbf{9 5}$ & $\mathbf{6 1}$ & $\mathbf{1 0 4}$ \\
\hline
\end{tabular}

Notes:

(1) the venue represents the place of the meeting was held extract from notice of the AGM meeting.

(2) timeliness represents the duration from the date notice of the AGM meeting to the date AGM meeting was held based on Bursa Announcement.

(3) Q\&A represents the questions and answers raised during the meeting by the shareholders that recorded by the AGM minutes from the corporate website.

(4) attendance list represents the list of board of directors, company secretary, and auditors during the AGM meeting was held that recorded by the AGM minutes from the corporate website.

(5) outcome resolution(s) represents the number of each resolution (in unit) and (in percentage) voted during the AGM meeting that recorded by the AGM minutes from the corporate website.

(6) chairman signatory represents the duly signed by the chairman on the end page of the AGM meeting was held that recorded by the AGM minutes from the corporate website.

(7) The duration of the meeting represents the timeframe from the meeting start until the closure of the meeting that can be captured based on the AGM minutes from the corporate website. 


\subsection{Results of each Quality AGM minutes on corporate website}

Based on Table 2, generally, the quality of AGM minutes on the corporate website provided mixed results. For the timeliness, from 115 listed companies, 111 (97 percent) disclosed the quality of AGM minutes on its corporate website followed by 88 (77 percent) which disclosed Q\&A, 72 (63 percent) which disclosed attendance list, 95 (83 percent) disclosed outcome resolution, 61 (53 percent) disclosed chairman signature and 104 (90 percent) disclosed the duration of the meeting.

In terms of timeliness, CA2016 specifically stressed that notice of the meeting must be published at least 28 days before the general meeting. For instance, the duration can be subdivided into less than 28 days, within 28 days and more than 28 days. For example, most of the companies tend to publish its notice of meeting more than 28 days before the general meeting except for Eversendai Berhad, Inch Kenneth Kajang Berhad, and KPJ Healthcare Berhad. Meanwhile, only 27 listed companies did not disclose Q\&A as part of AGM minutes on their corporate website. Using content analysis, it was found that most of the questions were answered well by the chairman and were recorded in the AGM minutes.

In addition, for the attendance list, only 63 percent were willing to disclose full attendance which shows that several companies are still reluctant to provide sensitive information, especially absentee directors. Interestingly, the outcome resolution of the AGM must be announced immediately after the general meeting. A few of the listed companies also take the initiative to disclose outcome resolution in the AGM minutes. This quality of AGM minutes can benefit the absentee shareholders or potential investors. Different from other qualities, the chairman's signature is most likely ignored by the listed companies. Hence, the chairman's signature represents the valid record of the documentation. However, several listed companies did not show the chairman's signature on its corporate website to avoid manipulation of the information. Lastly, the duration of the meeting shows that almost all listed companies comply with the regulation. The main contribution to this quality is because most of the companies have followed the Bursa Malaysia Securities Berhad AGM minutes as their benchmark. 


\subsection{CONCLUSION}

An AGM minute is a unique indicator of good governance. As there is not much study which focuses on the AGM minutes' context, this study will become a pioneer in observing in detail the content of AGM minutes. Using descriptive analysis, this study provides valuable information as the results indicate that the quality of AGM minutes is mostly associated with the timeliness and duration of meeting whereby from the 115 listed companies where their full AGM minutes were disclosed on the corporate website, only timeliness, and duration of the meeting were provided by more than 100 out of 115 listed companies. More importantly, this study shows that the awareness towards full disclosure of AGM minutes increased in 2016, most likely due to the mandatory listing requirements of key matters discussed to be published on the corporate website as soon as possible after the general meeting.

The company clearly followed the instruction from the directors in disclosing corporate information to the shareholders. Overall, with the generalisation of analysis, both financial or non-financial companies are willing to disclose the additional corporate information to the shareholders such as CIMB Group Holdings Berhad, Malayan Banking Berhad, and Public Bank Berhad.

\section{$5.1 \quad$ Contributions}

This study provides several contributions. Firstly, this study shows that awareness towards disclosure of AGM minutes on corporate website is receiving positive feedback by almost all listed companies. This supports the initiative conducted by the MSWG report, MalaysiaASEAN Corporate Governance report which annually assesses the quality of corporate governance upheld by the listed companies. Secondly, in terms of business practice, the increase of certain qualities in AGM minutes' disclosure aligns with prior studies that considers disclosure as a form of corporate legitimacy in business practices (Haniffa and Cook, 2005) as well as to reduce legitimacy gap (Newson and Deegan, 2002). Thirdly, the findings indicate the need for more extensive studies in the context of quality AGM minutes from the management (directors) and owners(shareholders) perspective.

\subsection{Limitation of the study}

However, this study also has some limitations. First, the examination of the content of AGM minutes of each company requires a degree of subjectivity that could reduce the reliability of 
the results. Therefore, future research can utilise a mixed method of qualitative and quantitative research approach. This study also focuses on a one-year examination horizon which is considered as a limitation by previous studies (Boesson and Kumar, 2007). The primary reason for the one-year study was due to the implementation of CA2016. Therefore, future studies should allow for a comparison between the situation before and after the implementation of CA2016, hence enabling the future study to provide more insight and meaningful results. Here, this study is open to more exploration on the main determinants leading toward AGM minutes' disclosure on corporate website.

\section{REFERENCES}

Akhtaruddin, M., \& Rouf, D. (2012). Corporate governance, cultural factors and voluntary disclosure: Evidence from selected companies in Bangladesh. Corporate Governance, Cultural Factors and Voluntary Disclosure: Evidence from Selected Companies in Bangladesh (June 1, 2012). Corporate Board: Role, Duties \& Composition, 8(1), 46-58.

Allegrini, M., \& Greco, G. (2013). Corporate boards, audit committees and voluntary disclosure: Evidence from Italian listed companies. Journal of Management \& Governance, 17(1), 187-216.

Ameer, R., \& Rahman, R. A. (2009). The Impact Of Minority Shareholder Watchdog Group Activism On The Performance Of Targeted Firms In Malaysia. Asian Academy of Management Journal of Accounting \& Finance, 5(1).

Apostolides, N. (2010). Exercising corporate governance at the annual general meeting. Corporate Governance: The International Journal of Business In Society.

Ariffin, M. S. M., Hussain, W. N. W., \& Malak, S. S. D. A. (2019). Disclosure Annual General Meeting Minutes on the Corporate Website: A Panacea toward a Good Governance. Indian-Pacific Journal of Accounting and Finance, 3(4), 4-13.

Avaniappan, S., \& Anuar, H. S. (2017). E-Services Effectiveness: A Case of Companies Commission of Malaysia. International Journal of Advanced Engineering Research and Science, 4(10). 
Ben-Amar, W., Chang, M., \& McIlkenny, P. (2017). Board gender diversity and corporate response to sustainability initiatives: Evidence from the carbon disclosure project. Journal of Business Ethics, 142(2), 369-383.

Bursa Malaysia Securities Berhad (2018). Listing Requirements. Bursa Malaysia, Kuala Lumpur.

Black, A., Taylor, P., Caley, R., \& Clark, R. (1998). The festival speech synthesis system.

Blueprint, C. G. (2011). Towards excellence in corporate governance. Securities Commission of Malaysia, Retrieved March, 9, 2012.

Brennan, N. M., \& Solomon, J. (2008). Corporate governance, accountability and mechanisms of accountability: an overview. Accounting, Auditing \& Accountability Journal, 21(7), 885-906.

Bryan, L., \& Farrell, D. (2009). ICSA International: Leading through Uncertainty (Part 1). Keeping Good Companies, 61(6), 350.

Cadbury Committee. Committee on the Financial Aspects of Corporate Governance. 1992. The Report of the Committee on the Financial Aspects of Corporate Governance. London.

Catasús, B., \& Johed, G. (2007). Annual general meetings-rituals of closure or ideal speech situations? A dual analysis. Scandinavian Journal of Management, 23(2), 168-190.

Certo, S. T. (2003). Influencing initial public offering investors with prestige: Signaling with board structures. Academy of Management Review, 28(3), 432-446.

Chan, W. M. (2017). Essential Company Law in Malaysia: Navigating the Companies Act 2016. Sweet \& Maxwell.

Chan, W. M. (2019). The Companies Act 1965. Journal of Malaysian and Comparative Law, 27, 207-230.

Chobpichien, Haron, \& Ibrahim, D. (2008). The quality of board of directors, ownership structure and level of voluntary disclosure of listed companies in Thailand. Euro Asia Journal of Management, 3(17), 3-39. 
Cordery, C. (2013). Regulating small and medium charities: Does it improve transparency and accountability?. Voluntas: International Journal of Voluntary and Nonprofit Organizations, 24(3), 831-851.

Council, F. R. (2012). The UK corporate governance code. London, September.

Cziraki, P., Renneboog, L., \& Szilagyi, P. G. (2010). Shareholder activism through proxy proposals: The European perspective. European Financial Management, 16(5), 738777.

Edmonds, C. T., Edmonds, J. E., Vermeer, B. Y., \& Vermeer, T. E. (2017). Does timeliness of financial information matter in the governmental sector?. Journal of Accounting and Public Policy, 36(2), 163-176.

Fama, E. F., \& Jensen, M. C. (1983). Agency problems and residual claims. The journal of law and Economics, 26(2), 327-349.

Fung, B. (2014). The demand and need for transparency and disclosure in corporate governance. Universal Journal of Management, 2(2), 72-80.

George, D., \& Mallery, P. (2010). SPSS for Windows step by step. A simple study guide and reference (10. Bask1). GEN, Boston, MA: Pearson Education, Inc.

González, G. P., Guzmán, A., Prada, F., \& Trujillo, M. A. (2014). Corporate governance practices at Annual general meetings in listed firms in Colombia. Cuadernos de Administración, 27(49), 37-64.

Guide, B. M. C. G. (2017). Kuala Lumpur. Bursa Malaysia.

Hamid, A. S. A., \& Dato'Seri, T. S. (1995). The civil service of Malaysia: Towards vision 2020. Government of Malaysia.

Helfaya, A., \& Moussa, T. (2017). Do board's corporate social responsibility strategy and orientation influence environmental sustainability disclosure? UK evidence. Business Strategy and the Environment, 26(8), 1061-1077. 
Ho, S. S., \& Wong, K. S. (2001). A study of the relationship between corporate governance structures and the extent of voluntary disclosure. Journal of International Accounting, Auditing and Taxation, 10(2), 139-156.

Kelton, A. S., \& Yang, Y. W. (2008). The impact of corporate governance on Internet financial reporting. Journal of Accounting and Public Policy, 27(1), 62-87.

La Porta, R., Lopez-de-Silanes, F., Shleifer, A., \& Vishny, R. (2000). Investor protection and corporate governance. Journal of Financial Economics, 58(1-2), 3-27.

Laksmana, I. (2008). Corporate board governance and voluntary disclosure of executive compensation practices. Contemporary accounting research, 25(4), 1147-1182.

López-Arceiz, F. J., Torres, L., \& Bellostas, A. J. B. A. J. (2019). Is online disclosure the key to corporate governance?. Online Information Review.

Malaysia-ASEAN Corporate Governance Report (2017). Retrieved from https://www.mswg.org.my/sites/default/files/AseanCG/2017/20171211_THE\%20EDG E\%20MALAYSIA\%20SPECIAL\%20REPORT.pdf dated September 9, 2019.

Malaysian Code on Corporate Governance (2017). Malayan Law Journal Sdn. Bhd., Kuala Lumpur.

Malaysian Corporate Governance Monitor (2019). Securities Commission of Malaysia. Retrieved from https://www.sc.com.my/api/documentms/download.ashx?id=98f99389-e438-454685e4-754717fa56ed dated September 9, 2019.

Malaysian Securities Commission. (2017). Malaysian code of corporate governance.

McGee, R., \& Gaventa, J. (2011). Shifting power? Assessing the impact of transparency and accountability initiatives. IDS Working Papers, 2011(383), 1-39.

Menon, J. (2017). Government-linked Companies: Impact on the Malaysian Economy. Policy IDEAS, (45).

Mohamad, S. (2002). Financial failures: any lessons, please?[Reprinted from The Chartered Secretary Malaysia, June 2002, a journal of MAICSA (Malaysian Association of the Institute of Chartered Secretaries and Administrators).]. Keeping Good Companies, 54(7), 392. 
Mort, S. (1995). Professional report writing. Gower Publishing, Ltd.

Najid, N. A., \& Rahman, R. A. (2011). Government ownership and performance of Malaysian government-linked companies. International Research Journal of Finance and Economics, 61(1), 1450-2887.

Nyahas, S. I., Ntayi, J. M., Kamukama, N., \& Munene, J. (2018). Stakeholders influence on voluntary disclosure practices by listed companies in Nigeria. International Journal of Law and Management.

OECD. (1999). Revenue Statistics: 1965-1998. Special Features, Taxing Powers of State and Local Government, The Interpretation of Tax-to-GDP Ratios, The Impact of GDP Revisions on Reported Tax Levels. OECD publishing.

Opler, T. C., \& Sokobin, J. S. (1995). Does coordinated institutional activism work? An analysis of the activities of the council of institutional investors.

Palmer, M. (2000). Records management and accountability versus corruption, fraud and maladministration. Records Management Journal, 10(2), 61-72.

Rita, B., \& Fern C. C. (2016). Understanding Key Information in an Annual Report-From a Minority Shareholder's Perspective. Kuala Lumpur, Malaysia. Retrieved from: https://www.mswg.org.my/sites/default/files/Understanding\%20key\%20infomation \%2 0o f\%20AR.pdf.

Salim, M. R. (2017). Reincarnating Malaysian Airline: Labour Rights from a Malaysian Perspective. International Company and Commercial Law Review, 28(1), 8.

Salleh, K., Hamid, N. A., Harun, N., Bidin, A., \& Abd Ghadas, Z. A. (2019). The Study On The Separation Of Ownership And Control Of Malaysian Companies. International Journal, 4(15), 36-44.

Securities Commission of Malaysia. (2020). The Malaysian Code of Governance. Retrieved from https://www.sc.com.my/api/documentms/download.ashx?id=70a5568b-19374d2b-8cbf-3aefed112c0a dated June 20, 2019.

Shackleton, F., Cordes, M., \& Caulfield, G. (2011). Shackleton on the Law and Practice of Meetings. Sweet \& Maxwell. 
Shih, L. (2018). The Companies Act 2016: Key Changes and Challenges. Journal of Malaysian and Comparative Law, 44(1. Jun.), 21-32.

Solomon, J. (2007). Corporate Governance and Accountability. John Wiley \& Sons.

Tabachnick, B. G., Fidell, L. S., \& Ullman, J. B. (2007). Using multivariate statistics (Vol. 5). Boston, MA: Pearson.

Transparency International. (2017). Corruption perceptions index 2017.

Wahab, E. A. A., How, J., \& Verhoeven, P. (2008). Corporate governance and institutional investors: evidence from Malaysia. Asian Academy of Management Journal of Accounting and Finance, 4(2), 67-90.

Yang, A., Uysal, N., \& Taylor, M. (2018). Unleashing the power of networks: Shareholder activism, sustainable development and corporate environmental policy. Business Strategy and the Environment, 27(6), 712-727.

Zeng, T. (2016). Corporate social responsibility, tax aggressiveness, and firm market value. Accounting Perspectives, 15(1), 7-30.

Zulkifli, K. S. A. (2019). The influence of firm characteristics and corporate governance attributes towards intellectual capital reporting practices of companies listed on the main market of bursa Malaysia (Doctoral dissertation, Universiti Teknologi MARA). 